\title{
Yarı Kurak Alanlarda Mikro Havza Su Hasadı Uygulamalarının Toprak Nemine Etkilerinin Belirlenmesi
}

\author{
İlknur CEBECi*1 Oğuz BAȘKAN'ำ Osman MÜCEVHER² Yakup KÖȘKER' Hicrettin CEBEL' \\ Oğuz DEMIRKIRAN' Ödül ÖZTÜRK' Erdal GÖNÜLAL ${ }^{2}$
}

'Toprak Gübre ve Su Kaynakları Merkez Araștırma Enstitüsü Müdürlüğü, Ankara

${ }^{2}$ Toprak Su ve Çölleșme ile Mücadele Araștırma Enstitüsü Müdürlüğü, Konya

*Sorumlu yazar e-mail (Corresponding author e-mail): ilknur.cebeci@tarim.gov.tr

Geliș tarihi (Received) : 21.11.2016

Kabul tarihi (Accepted): 28.02.2017

DOI : $10.21657 /$ topraksu.339819

\section{Öz}

Dünya nüfusunun ve artan su talebiyle sınırlı su kaynaklarına baskının artması nedeniyle, çalıșmalar daha etkili su kullanımı üzerine yoğunlașmıștır. Etkili su kullanım yollarından biri de yağmur suyu hasadı yöntemidir. Bu çalıșmada, yarı kurak özelliğe sahip Karapınar Çölleșme ve Erozyon Araștırma Merkezi'nde bitkisel üretim için toprak neminin arttırıması amaçlanmıștır. Çalıșmada mikro havza su hasadı yöntemlerinden sırt ve karık sistemi uygulanmıștır. Farklı sırt genișliklerinin ve farklı kaplama malzemelerinin toprak nemine etkilerinin araștırıldığı çalıșmada, kavun yetiștiriciliği için, su hasadı konuları olarak üç farklı sırt genișliği $\left(g_{1}=30 \mathrm{~cm}, g_{2}=45 \mathrm{~cm}\right.$ ve $\left.g_{3}=60 \mathrm{~cm}\right)$ ve iki farklı kaplama malzemesi $(P=$ plastik malç ve $S=$ saman malç) ile sıkıștırılmıș toprak sırt (T) uygulanmıș ve kontrol konusu geleneksel toprak ișleme yöntemiyle düz arazi üzerinde kurulmuștur. Hasat edilen yağmur suyunun toplanması için sabit 50 cm genișliğinde karıklar bırakılmıș ve bu karıklarda kavun yetiștirilmiștir. Deneme tesadüf bloklarında bölünmüș parseller deneme desenine göre üç tekrarlı yürütülmüștür. Tüm konularda toprak nemi $90 \mathrm{~cm}$ derinliğe kadar nötron metre ile takip edilmiștir. Bitki yetișme dönemi boyunca en fazla yağıș 46.6 mm ile 2015 yılı haziran ayında düșmüștür. Yağıșlı dönem sonrası hemen yapılan toprak nemi ölçümlerine göre en yüksek nem 294.6 mm ortalama ile plastik örtü uygulanan $60 \mathrm{~cm}$ sırt genișliğine sahip $\mathrm{Pg}_{3}$ konusunda saptanmıștır. Bunu sırasıyla Pg $(277.8 \mathrm{~mm}), \mathrm{Pg}_{1}(261.9$ $\mathrm{mm}$ ), Sg (209.3 mm), Sg$(205.9 \mathrm{~mm}), \mathrm{Sg}_{2}(204 \mathrm{~mm}), \mathrm{Tg}_{1}(200.3 \mathrm{~mm}), \mathrm{Tg}_{2}$ (194.9 mm) ve $\mathrm{Tg}_{3}(194.8$ mm) konuları izlemiș, kontrol konusu 170.2 mm ile toprak nemi açısından en son sırada yer almıștır. Bütün çalıșma süresi boyunca yapılan ölçümlerde en fazla toprak neminin $\mathrm{Pg}_{3}$ konusunda olduğu gözlemlenmiștir. Su hasadı uygulamaları ile özellikle plastik örtülü sırtlarda çok az miktardaki bir yağıșın bile toprak nemini artırdığı saptanmıștır. Sırt genișliğinin artmasıyla toprakta nem birikiminin artmıș olmasına rağmen, Karapınar bölgesinde yeterli yağıș olmamasından dolayı pazar değeri olan kavun verimi elde edilememiștir.

Anahtar Kelimeler: Toprak nemi, su hasadı, sırt/karık oranı, kurak-yarı kurak alan, yağıș

\section{Determination Effects of Micro-Catchment Water Harvesting Applications to Soil Moisture in Semi-Arid Regions}

\footnotetext{
Abstract

Due to increasing world population and increasing water demand pressure on limited fresh water resources, studies have focused on more effective water uses. One of the effective water using ways is rainwater harvesting. In this study it was intended to increase soil moisture for crop production in semi-
} 
arid areas in Karapınar Desertification and Erosion Research Center. Ridge and furrow system called micro catchment water harvesting methods were applied in the study. The effects of different ridge widths and different covering materials on soil moisture were investigated. The treatments consisted of three ridge widths $\left(g_{1}=30 \mathrm{~cm}, g_{2}=45 \mathrm{~cm}\right.$ and $g_{3}=60 \mathrm{~cm}$ ) and two different covering materials ( $P=$ plastic mulch and $S=$ straw mulch) and compressed soil ridge (T) as rain water harvesting application and a conventional soil cultivation and growing melon on flat area as a control. A fixed $50 \mathrm{~cm}$-width furrows were left to allow harvested rain water infiltration and also to grow melon in water harvesting treatments. The experiment was conducted in a randomized complete block design with split block with three replications. In all plots soil moiture was monitored with a neutron meter up to $90 \mathrm{~cm}$ depth. During the growing period the highest precipitation was $46.6 \mathrm{~mm}$ in Jun 2015 . According to soil moisture measurements after the rainy period, the highest soil moisture content was $294.6 \mathrm{~mm}$ in $0-90 \mathrm{~cm}$ deep at plastic covered ridge which had $60 \mathrm{~cm}$ ridge width at $30 \mathrm{Jun} 2015$. After that, decreasing order of soil moisture were $\mathrm{Pg}_{2}(277.8 \mathrm{~mm}), \mathrm{Pg}_{1}(261.9 \mathrm{~mm}), \mathrm{Sg}_{3}(209.3 \mathrm{~mm}), \mathrm{Sg}_{1}(205.9$ $\mathrm{mm}), \mathrm{Sg}_{2}(204 \mathrm{~mm}), \mathrm{Tg}_{1}(200.3 \mathrm{~mm}), \mathrm{Tg}_{2}(194.9 \mathrm{~mm})$ and $\mathrm{Tg}_{3}(194.8 \mathrm{~mm})$. The control plot had the least soil moisture with $170.2 \mathrm{~mm}$. The highest soil moisture was determined in $\mathrm{Pg}_{3}$ during the trial period. It was observed that even a small amount of precipitation caused increases in soil moisture for water harvesting treatments especially in the plastic covered ridge plots. Although the increased accumulation of moisture in the soil with increased ridge width it wasn't obtained marketable melon yield in Karapınar region due to lack of enough precipitation.

Key words: Soil moisture, water harvesting, ridge/furrow ratio, arid and semi-arid areas, precipitation

\section{Giriș}

Küresel olarak günden güne artan su talebine karșın tarımda kullanılan su miktarı kısıtlanmakta ve dünya gıda güvenliği tehlikeye girmektedir. Sürekli artan gıda ve su talebini karșılamaya yönelik çözüm önerileri kapsamında yağmur suyundan etkin bir șekilde yararlanmanın önemi giderek artmaktadır. Su kısıtı olan alanlarda tarımsal üretim için su hasadı, su toplama havzasından derlenen suyun daha küçük bir alan içerisinde veya bitki kök bölgesinde depolanmasıdır (Boers ve Ben-Asher, 1982; Oweis ve Hachum, 2000). Bu yöntemde toplanan yağıș suları yüzey akıș alanının hemen yanındaki ekim alanında sulama amaçlı kullanılmakta ya da daha sonra kullanılmak üzere depolanmaktadır (Pamuk Mengü ve Akkuzu, 2008). Su hasadı yönteminin tarihi oldukça eski olup, yüzyıllardır geleneksel yöntemlerle pek çok ülkede denenmiș olmasına rağmen bu konuda yapılan bilimsel araștırma oldukça sınırıdır. Olumsuz iklim koșulları ile bașa çıkmak için geçmișten beri kullanılan yağmur suyu hasadı sistemi Boers vd. (1986) tarafından tarif edilmiștir. Bu yöntemlerden biri olan sırt ve karık yağmur suyu hasat sisteminde, sırtlardan hasat edilen su karıklarda infiltre olarak toprakta depolanır (Wang vd, 2008). Sulama yapılmayan ve yağıșa dayalı tarımın yapıldığı bölgelerde yağıș miktarındaki azalmaların, ürün miktarını olumsuz yönde etkilemesi kaçınılmazdır. Yüzey akıș sadece yağıș olduğu zaman hasat edilebilir. Bitkilerin tamamının yağıșlarla beslendiği bazı bölgelerde yıllık yağıșlarda \%50'ye varan bir azalma, toplam üründe büyük bir düșüșe sebep olabilir (Critchley ve Siegert 1991). Mikro havza su hasadı yöntemleri ile yağıș miktarı az olsa bile mevcut yağıșın toplanmasıyla bitki gelișimi sağlanabilmektedir.

Sırt:karıkyöntemiyleÇin'deyapılanaraștırmalarda Li vd. (2000) sıkıștırımıș toprak sırtlardan \%7'lik bir yüzey akıș etkinliği elde ederken plastik malçlı sırtlardan ortalama olarak \%87 elde etmiștir. Yine Li vd. (2001) plastik malçlı sırt konusunda kontrole göre mısır veriminde ilk yıl \%92, ikinci yıl \%21 ürün artıș elde etmiștir. Wang vd. (2008) tarafından patates yumru veriminin plastik malçlı sırtlarda \%158.6-175.0 oranında bir artıșla geleneksel ekimden oldukça yüksek olduğu, sıkıștııılmıș toprak sırtlarda ise \%14.9-28.4 oranında ortalama verim artıșı tespit edilmiștir. Yapılan bu çalıșmada olduğu gibi plastik kaplı sırtlarda toprak nem içeriği sıkıștırılmıș toprak sırtlardan daha yüksek ve her ikisinde de kontrol konusundan daha yüksek bulunmuștur.

Ülkemizde su hasadı çalıșmaları son yıllarda önem kazanmıș olup, farklı iklim koșullarında konu ile ilgili yapılan çalıșma sayısı günden güne artmaktadır. Bu çalıșmanın amacı farklı sırt 
genișlikleriyle birlikte malç uygulamalarının bitki kök bölgesinde toprak nem korunumuna etkisinin belirlenmesidir.

\section{MATERYAL ve YÖNTEM}

Çalıșma, Konya Toprak Su ve Çölleșme ile Mücadele Araștırma Enstitüsü Karapınar Çölleșme ve Erozyon Araștırma Merkezi'nde yürütülmüștür
(Șekil 1). Konya'nın 95 km doğusunda bulunan Karapınar'da yağıșların az olması ve yer üstü sularının yetersizliği ilçede kuru tarımı ön plana çıkarmaktadır (Anonim, 2016a).

Çalıșma alanı topraklarına ait bazı fiziksel ve kimyasal analizler Çizelge 1.'de verilmiștir. Killi tınlı bünyeye sahip topraklarda kireç oranı oldukça fazla, organik madde miktarı düșük düzeydedir.

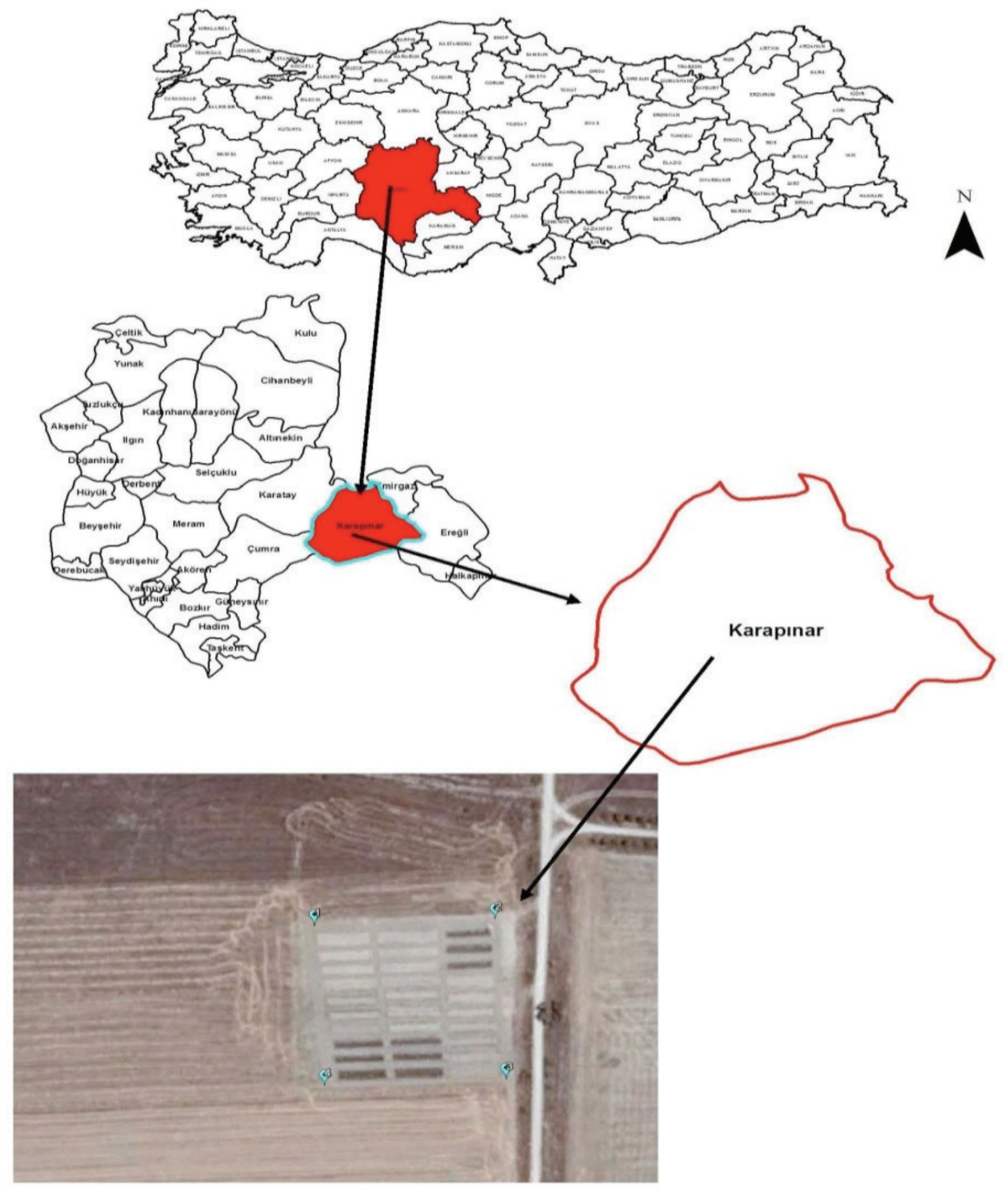

Şekil 1. Deneme alanının konumu

Figure 1. Location of experimental site 
Çizelge 1. Çalıșma alanı topraklarının bazı fiziksel ve kimyasal özellikleri

Table 1. Some physical and chemical characteristics of soil in experimental site

\begin{tabular}{|c|c|c|c|c|c|c|c|c|c|c|c|}
\hline \multirow{2}{*}{$\begin{array}{l}\text { Derinlik } \\
(\mathrm{cm})\end{array}$} & \multirow{2}{*}{$\begin{array}{c}E C \\
(\mathrm{ds} / \mathrm{m})\end{array}$} & \multirow{2}{*}{$\begin{array}{l}\text { Toplam } \\
\text { Tuz } \\
(\%)\end{array}$} & \multirow{2}{*}{$\mathrm{pH}$} & \multirow{2}{*}{$\begin{array}{l}\text { Kireç } \\
(\%)\end{array}$} & \multicolumn{2}{|c|}{$\begin{array}{c}\text { Bitkilere Yarayıșlı } \\
\text { Besin Maddeleri } \\
\left(\mathrm{kg} \mathrm{da}^{-1}\right)\end{array}$} & \multirow{2}{*}{$\begin{array}{l}\text { Organik } \\
\text { Madde } \\
(\%)\end{array}$} & \multirow{2}{*}{$\begin{array}{l}\text { Suyla Doy- } \\
\text { gunluk (\%) }\end{array}$} & \multirow{2}{*}{$\begin{array}{l}\text { TK } \\
(\%)\end{array}$} & \multirow{2}{*}{$\begin{array}{l}\text { SN } \\
(\%)\end{array}$} & \multirow{2}{*}{$\begin{array}{c}\text { Hacim } \\
\text { Ağırlığı } \\
(\mathrm{gr} \\
\left.\mathrm{cm}^{-3}\right)\end{array}$} \\
\hline & & & & & $\begin{array}{l}\text { Fosfor } \\
\left(\mathrm{P}_{2} \mathrm{O}_{5}\right)\end{array}$ & $\begin{array}{l}\text { Pota- } \\
\text { syum } \\
\left(\mathrm{K}_{2} \mathrm{O}\right)\end{array}$ & & & & & \\
\hline $0-30$ & 0.78 & 0.02 & 7.74 & 59.66 & 1.32 & 33.65 & 0.38 & 63.67 & 28.22 & 15.11 & 1.23 \\
\hline $30-60$ & 1.59 & 0.03 & 7.72 & 61.37 & 1.39 & 30.11 & 0.20 & 68.33 & 29.11 & 16.16 & 1.27 \\
\hline $60-90$ & 1.51 & 0.05 & 7.86 & 56.57 & 0.99 & 24.96 & 0.23 & 69.67 & 44.72 & 23.79 & 1.4 \\
\hline
\end{tabular}

Çizelge 2. Çalıșma alanı yağıș ve sıcaklık verileri

Table 2. Precipitation and temperature data of experimental site

\begin{tabular}{|c|c|c|c|c|c|c|c|c|c|c|c|c|c|}
\hline YII/Ay & Ocak & Șubat & Mart & Nisan & Mayıs & Haziran & Temmuz & Ağustos & Eylül & Ekim & Kasım & Aralık & Top./Ort \\
\hline \multicolumn{14}{|c|}{ YAĞIȘ (mm) } \\
\hline $\begin{array}{l}\text { Uzun } \\
\text { Yıllar }\end{array}$ & 24.6 & 22.7 & 18.8 & 25.3 & 23.2 & 23.7 & 5.8 & 2.6 & 10.3 & 17.4 & 21.0 & 32.8 & 228.2 \\
\hline 2014 & 40.4 & 18.4 & 47.2 & 3.2 & 18.4 & 26.0 & 0 & 9.8 & 17.2 & 48.2 & 31.8 & 29.8 & 290.4 \\
\hline 2015 & 13.2 & 24.9 & 42.6 & 16.2 & 28.0 & 46.6 & 0 & 5.2 & 0.8 & 3.6 & 1.6 & 0.6 & 183.3 \\
\hline \multicolumn{14}{|c|}{ SICAKLIK $\left({ }^{\circ} \mathrm{C}\right)$} \\
\hline $\begin{array}{l}\text { Uzun } \\
\text { Yıllar }\end{array}$ & 0.2 & 1.5 & 5.8 & 10.8 & 16.2 & 20.5 & 24.0 & 23.3 & 18.0 & 12.0 & 5.7 & 1.7 & 11.6 \\
\hline 2014 & 2.4 & 3.9 & 7.5 & 12.8 & 16.1 & 19.3 & 26.1 & 24.0 & 18.6 & 11.8 & 5.8 & 5.5 & 12.8 \\
\hline 2015 & 0.7 & 2.8 & 6.6 & 8.6 & 15.4 & 22.1 & 24.7 & 23.4 & 20.6 & 13.8 & 2.3 & -2.7 & 11.5 \\
\hline
\end{tabular}

Karapınar bölgesinin iklimi yarı-kurak karasal iklimi olup yazlar sıcak ve kurak, kıșlar yaz aylarına oranla soğuk ve yağıșııdır. Türkiye'nin en az yağıș alan yerlerinden biri olan Karapınar'ın uzun yıllar (1996-2015) iklim verilerine göre yıllık ortalama sıcaklık $11.6^{\circ} \mathrm{C}$ ve yıllık yağıș miktarı 228.2 mm'dir (MGM, 2016) ve bunun çoğunluğu kıș aylarında düșmektedir. Bölgede haziran-eylül ayları arasında düșen yağıș miktarı yağıșa dayalı tarım faaliyetleri için oldukça düșüktür (Çizelge 2). Bitki yetișme

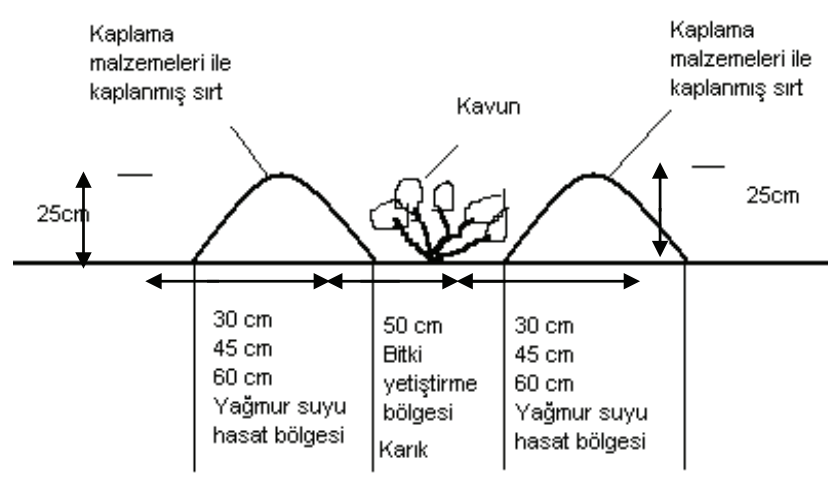

Șekil 2. Uygulanan farklı sırt/karık oranları Figure 2. Applied different ridge / furrow rates dönemindeki ortalama sıcaklık 2014 yılında 21.9 ${ }^{\circ} \mathrm{C}$ ve 2015 yılında $22.3^{\circ} \mathrm{C}$ ölçülmüștür.

Çalıșmada uygulanan sırt/karık oranları; 30:50 $\mathrm{cm}, 45: 50 \mathrm{~cm}$ ve $60: 50 \mathrm{~cm}$ olup her genișlikteki sırtlardan su hasadı için plastik örtü, buğday ve arpa gibi bitkilerin sap ve samanı ve sıkıștırılmıș toprak sırtlar kullanıımıștır (Șekil 2).

Deneme, plastik örtünün (P), sap-saman kaplamanın (S) ve malçsız toprak sıkıștırmasının (T), $g_{1}=30 \mathrm{~cm}, g_{2}=45 \mathrm{~cm}$ ve $g_{3}=60 \mathrm{~cm}$ genișliğindeki sırtlara uygulandığı konular ve kontrol olmak üzere on konudan olușmuștur. Plastik örtü ve sap saman üzerine serilen \%15 gölgelikli file, sırtlara 2-3 mm kalınlıkta galvanizli çelik tel $U$ șeklinde eğilerek sabitlenmiștir. Toprak sırtlar ise ahșap tokmakla sıkıștırılmıștır (Resim 1).

Tesadüf bloklarında bölünmüș parseller deneme desenine göre üç tekerrürlü yürütülen çalıșmada bitki olarak kavun kullanılmıștır. Denemede kullanılan Edalı F1 hibrit kavun fideleri hazır fide firmasından temin edilmiștir. Kontrol 

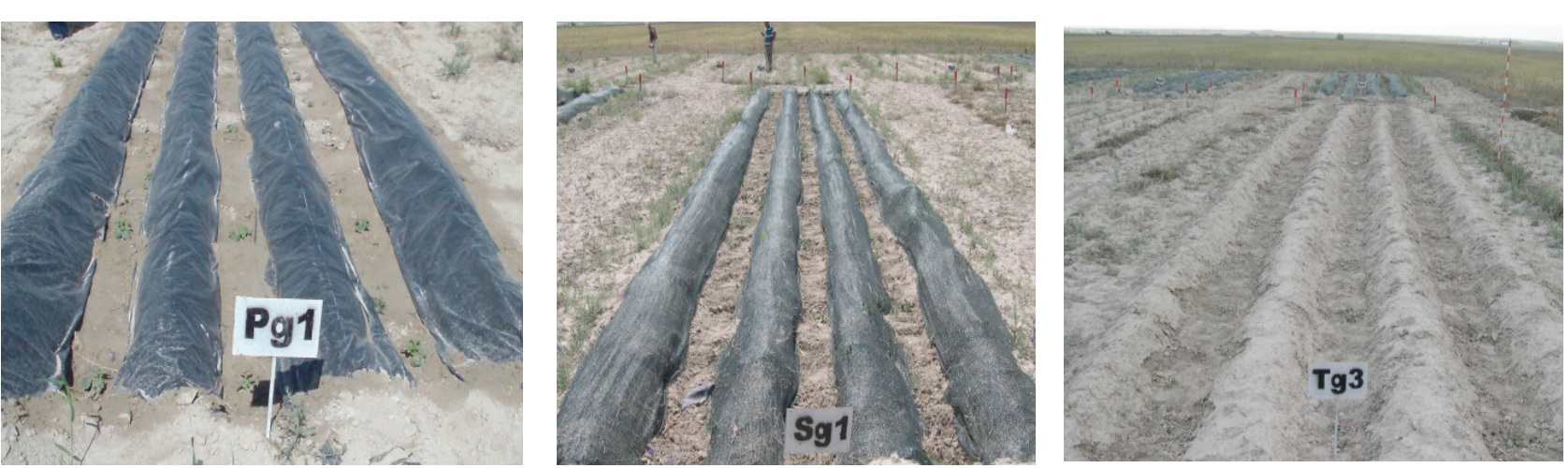

Resim 1. Uygulanan farklı sırt/karık oranları

Photo 1. Experimental subjects

konusu hariç her parselde dört sırt ve üç karık yapılmıș ve her bir karığa on adet bitki dikilmiștir. Karıklarda her iki bitki sıra üzeri $150 \mathrm{~cm}$ mesafe bırakılmıștır. Sabit $50 \mathrm{~cm}$ karık genișliği için $g_{1}, g_{2}$ ve $g_{3}$ konularında sırasıyla bitki sıra araları $80 \mathrm{~cm}$, $95 \mathrm{~cm}$ ve $110 \mathrm{~cm}$ 'dir. Bütün parsellerin uzunlukları eșit olup parsel enleri Feng vd. (2012)'de olduğu gibi uygulanan sırt genișliğine bağlı olarak farklıdır. Buna göre sabit $50 \mathrm{~cm}$ karık genișliği için $g_{1}$ konusunda $2.70 \mathrm{~m}, g_{2}$ konusunda $3.30 \mathrm{~m}$ ve $g_{3}$ konusunda $3.90 \mathrm{~m}$ parsel eni olmuștur. Kontrol konusu için sırtsız düz arazi üzerine sıra üzeri 150 $\mathrm{cm}$ ve sıra arası $50 \mathrm{~cm}$ olan parseller kurulmuștur

İlk yıl 15 Mayıs 2014 ve ikinci yıl 14 Mayıs 2015 tarihlerinde parsellere kavun fideleri dikilmiștir. Taban gübresi olarak dikimde $16 \mathrm{~kg} \mathrm{da}^{-1}$ DAP ve $10 \mathrm{~kg} \mathrm{da}^{-1}$ potasyum sülfat, üst gübre olarak $20 \mathrm{~kg}$ $\mathrm{da}^{-1}$ amonyum sülfat uygulanmıștır. Kavun hasadı tek seferde olmak üzere ilk yıl 3 Eylül 2014 ve ikinci yıl 8 Eylül 2015 tarihlerinde yapılmıștır.

Denemede kavun yetișme dönemi boyunca toprak nem içeriği her parselde 0-30 cm, 30-60 $\mathrm{cm}$ ve $60-90 \mathrm{~cm}$ derinliklerden 15 ila 30 gün arasında CPN 503 DR Hydroprope model nötron prob cihazı ile takip edilmiș ve ayrıca gravimetrik yöntem kullanılarak belirlenmiștir. Deneme parsellerinde ölçüm karığı olan orta karığa 5 $\mathrm{cm}$ çapında alüminyum akses tüpler çakılmıștır. Nötronmetre ile alınan standart sayım oranları ile derinliklere göre toprağın hacimsel nem içeriği arasındaki ilișki regresyon analizi ile $\left(R^{2}{ }_{30 \mathrm{~cm}}=0.95\right.$, $R_{60 \mathrm{~cm}}^{2}=0.94$ ve $R_{90 \mathrm{~cm}}^{2}=0.94$ ) belirlenmiștir.

Çalıșmada elde edilen toprak nem verilerinin ortalama, minimum, maksimum, standart sapma, değișim katsayısı gibi tanımlayıcı istatistikleri SPSS istatistik programı ile yapılmıștır. Uygulamalar arasındaki fark varyans analizi (ANOVA) ile karșılaștıııımıș, farkın önemli olduğu konularda çoklu karșılaștırma (Duncan) yöntemleri ile uygulamalar gruplandırımıștır. Sonuçlar \%5 hata düzeyinde değerlendirilmiștir. Aylık toplam yağıș verilerinin istatistiksel olarak değerlendirilmesi SPSS paket programında, nötronmetre kalibrasyon eğrisini olușturmak için regresyon analizi Microsoft Excel 2010 programında yapılmıștır.

\section{BULGULAR ve TARTIȘMA}

Karapınar Cölleșme ve Erozyon Araștırma Merkezi'nde bulunan otomatik meteoroloji gözlem istasyonundan (OMGi) alınan verilere göre toplam yağıș miktarı 2014 yılında 290.4 mm, 2015 yllında 183.3 mm'dir (Çizelge 2). Çalıșmanın yapııdığı 2014 yılı 15 Mayıs- 3 Eylül tarihleri arasında toplam yağıș 44.2 mm, 2015 yılı 13 Mayıs- 8 Eylül tarihleri arasında toplam yağıș 70.8 mm'dir (Çizelge 3). Bir yağıș olayında 5 mm'den düșük yağıșlar inmal edilmiș (Faberio vd. 2001) ve 5 mm'den yüksek yağıșlar etkili yağıș olarak kabul edilmiștir (Tian vd. 2003; Li vd. 2007). Buna göre bitki yetișme dönemindeki etkili yağıș miktarı 2014 yılında 30.6 mm ve 2015 yılında $44 \mathrm{~mm}$ olmuștur. Bitki yetișme dönemi boyunca günlük yağıș dağılımı Çizelge 3'te verilmiștir.

Kontrol (K) konusu geleneksel ekim yöntemi ile olușturulmuș ve herhangi bir su hasadı uygulaması yapılmadan doğrudan meteorolojik șartların etkisi altında bırakılmıștır. Buharlașma kayıpları (düz arazide) tüm uygulamalar için aynıdır. Bu nedenle kontrol için farklı sıra aralarını içeren uygulama yapılmamıștır. İstatistiksel değerlendirmeler yukarıda açıklandığı gibi sıra aralarının açık meteorolojik șartlara bırakılan kontrol parsellerinden olan buharlașmanın tamamını temsil edeceği düșüncesiyle yapılmıștır. 
Çizelge 3. Bitki yetișme dönemi boyunca günlük yağıș dağııımı

Table 3. Daily precipitation during the plant growing season

\begin{tabular}{|c|c|c|c|c|c|}
\hline \multicolumn{6}{|c|}{ Günlük yağıșlar (mm) } \\
\hline \multicolumn{2}{|c|}{2014} & \multicolumn{4}{|c|}{2015} \\
\hline Tarihi & Miktarı & Tarihi & Miktarı & Tarihi & Miktarı \\
\hline 23 Mayıs & 7.6 & 22 Mayıs & 3.4 & 9 Haziran & 3.4 \\
\hline 24 Mayıs & 0.8 & 24 Mayıs & 1.0 & 10 Haziran & 1.8 \\
\hline 1 Haziran & 1.4 & 27 Mayıs & 0.6 & 11 Haziran & 8.8 \\
\hline 2 Haziran & 2.8 & 28 Mayıs & 0.6 & 18 Haziran & 0.4 \\
\hline 3 Haziran & 0.4 & 29 Mayıs & 7.6 & 25 Haziran & 2.0 \\
\hline 4 Haziran & 0.2 & 30 Mayıs & 5.8 & 26 Haziran & 1.4 \\
\hline 5 Haziran & 0.8 & 1 Haziran & 0.2 & 4 Ağustos & 1.4 \\
\hline 6 Haziran & 1.6 & 2 Haziran & 12.2 & 6 Ağustos & 0.8 \\
\hline 7 Haziran & 2.4 & 3 Haziran & 9.6 & 15 Ağustos & 0.4 \\
\hline 8 Haziran & 13.2 & 4 Haziran & 4.0 & 16 Ağustos & 0.6 \\
\hline 9 Haziran & 0.8 & 5 Haziran & 0.8 & 24 Ağustos & 2.0 \\
\hline 10 Haziran & 1.6 & 6 Haziran & 0.2 & & \\
\hline 16 Haziran & 0.8 & 7 Haziran & 0.6 & & \\
\hline 5 Ağustos & 9.8 & 8 Haziran & 1.2 & & \\
\hline Toplam & 44.2 & Toplam & 70.8 & & \\
\hline
\end{tabular}

Etkili yağıș toplamı 30.6

44.0

Toprak nem değerlerinin istatistiksel değerlendirmesi sonucunda 2014 yılında standart sapma $21.2 \mathrm{~mm}$, ortalama $162.5 \mathrm{~mm}$, minimum değer 130.4 mm ve maksimum değer 207.6 mm iken 2015 yılında bu değerler sırasıyla $27.1 \mathrm{~mm}, 155.6 \mathrm{~mm}, 117.6 \mathrm{~mm}$ ve $220.3 \mathrm{~mm}$ bulunmuștur. Toprak nem verilerinin yıllar bazında değerlendirmesinde varyans analizi sonuçlarına göre sırt kaplama malzemesi ve sırt genișliği interaksiyonu bakımından 2014 yılında istatistiksel olarak önemsiz olup, 2015 yllında ise interaksiyon istatistiksel olarak \%5 düzeyinde önemli bulunmuș ve Duncan gruplandırması yapılmıștır. Buna göre 0-90 cm'de konulara göre ortalama toprak nem değerleri Çizelge 4'te verilmiștir.

Çizelge 4'e göre 2014 yilında en fazla toprak nemi ortalama $195.2 \mathrm{~mm}$ ile $\mathrm{Pg}_{3}$ konusunda belirlenmiș, bunu sırasıyla $\mathrm{Pg}_{2}, \mathrm{Pg}_{1}, \mathrm{Sg}_{2^{\prime}} \mathrm{Sg}_{3^{\prime}}, \mathrm{Sg}_{1}$, $\mathrm{Tg}_{1}, \mathrm{Tg}_{2}$ ve $\mathrm{Tg}_{3}$ konuları izlemiș, en az toprak nemi 149.5 mm ile kontrol konusunda olmuștur. İnteraksiyonun önemli çıktığı 2015 yılında Duncan gruplandırmasında deneme konularına göre toprak nemi dokuz gruba ayrılmıs ve $213.8 \mathrm{~mm}$ ile 128.0 mm arasında değișim göstermiștir. En
Çizelge 4. Yıl bazında deneme konularının toprak nemine etkileri

Table 4. The effects of the experimental subjects on soil moisture by years

\begin{tabular}{ccc}
\hline & \multicolumn{2}{c}{ Ortalama Toprak Nemi $(\mathrm{mm})$} \\
\cline { 2 - 3 } Konular & 2014 & 2015 \\
\hline $\mathrm{Pg}_{1}$ & 187.6 & $176.2 \mathrm{C}$ \\
$\mathrm{Pg}_{2}$ & 193.1 & $192.8 \mathrm{~b}$ \\
$\mathrm{Pg}_{3}$ & 195.2 & $213.8 \mathrm{a}$ \\
$\mathrm{Sg}_{1}$ & 148.3 & $153.7 \mathrm{def}$ \\
$\mathrm{Sg}_{2}$ & 161.8 & $155.5 \mathrm{de}$ \\
$\mathrm{Sg}_{3}$ & 155.5 & $161.1 \mathrm{~d}$ \\
$\mathrm{Tg}_{1}$ & 156.6 & $138.5 \mathrm{fg}$ \\
$\mathrm{Tg}_{2}$ & 152.7 & $140.2 \mathrm{efg}$ \\
$\mathrm{Tg}_{3}$ & 150.9 & $148.6 \mathrm{def}$ \\
$\mathrm{K}$ & 149.5 & $128.0 \mathrm{~g}$ \\
\hline
\end{tabular}

fazla toprak nemi 2014 yllında olduğu gibi, $\mathrm{Pg}_{3}(\mathrm{a})$ konusunda olmuș, bunu sırasıyla $\mathrm{Pg}_{2}$ (b), $\mathrm{Pg}_{1}$ (c), $\mathrm{Sg}_{3}$ (d), $\mathrm{Sg}_{2}$ (de), $\mathrm{Sg}_{1}$ (def), $\mathrm{Tg}_{3}$ (def), $\mathrm{Tg}_{2}$ (efg), $\mathrm{Tg}_{1}$ (fg) ve K (g) konuları takip etmiștir. Her iki yılda da elde edilen sonuçlara göre, sırt: karık sisteminin 
uygulandığı Li vd. (2007)'ye benzer șekilde, en fazla toprak nemi plastik malçlı sırt konularında belirlenmiștir. Bunu sırasıyla sap- saman ve toprak sırt konuları takip etmiș, en az toprak nemi ise geleneksel yöntemle kurulmuș kontrol konusunda saptanmıștır.

Toprak nem verileri malç materyalleri bakımından değerlendirildiğinde her iki yılda da konular arasındaki fark istatistiksel olarak \%5 düzeyinde önemli bulunmuștur.

Çizelge 5. Sırt kaplama malzemesine göre 2014 ve 2015 yılları toprak nemi grupları

Table 5. Groups of soil moisture for the years 2014 and 2015 according to ridge covering material

\begin{tabular}{lcc}
\hline \multirow{2}{*}{ Malç Materyali } & \multicolumn{2}{c}{$\begin{array}{c}\text { Ortalama Toprak Nemi }(0-90 \mathrm{~cm} \\
(\mathrm{mm})\end{array}$} \\
\cline { 2 - 3 } & 2014 & 2015 \\
\hline Plastik malç & $191.9 \mathrm{a}$ & $194.3 \mathrm{a}$ \\
Sap-saman & $155.2 \mathrm{~b}$ & $156.8 \mathrm{~b}$ \\
Toprak & $153.4 \mathrm{c}$ & $142.4 \mathrm{c}$ \\
Kontrol & $149.5 \mathrm{~d}$ & $128.8 \mathrm{~d}$ \\
\hline
\end{tabular}

Sırt kaplama malzemesi bakımından ortalama toprak nemi 2014 yılında $149.5 \mathrm{~mm}$ ile $191.9 \mathrm{~mm}$ arasında, 2015 yılında $128.8 \mathrm{~mm}$ ile $194.3 \mathrm{~mm}$ arasında değișim göstermiștir. Her iki yılda da ortalama toprak nemi dört gruba ayrılmıș olup en yüksek toprak nemi plastik malç uygulamalarında (a) olup bunu sırasıyla sap-saman (b) ve toprak sırt (c) konuları takip etmiștir. En düșük toprak nemi ise kontrol konularında (d) belirlenmiștir (Çizelge 5). Bu sonuçları destekler șekilde Li vd. (2000) tarafından sırt:karık mikro havza su hasadında plastik örtülü sırtlarda $0.8 \pm 0.2 \mathrm{~mm}$ nin üstünde yağıșların yüzey akıș olușturduğu, sıkıștırılmıș sırtlarda ise toprak infiltrasyon hızından daha yüksek hızdaki yağıșlarda yüzey akıș oluștuğu saptanmıștır.

Toprak nem verileri sırt genișliği bakımından değerlendirildiğinde konular arasındaki fark istatistiksel olarak 2014 yılında önemsiz olup 2015 yılında istatistiksel olarak \%5 düzeyinde önemli bulunmuș ve Duncan gruplandırması yapılmıștır (Cizelge 6).

Çizelge 6'ya göre 2015 yılında ortalama toprak nemi iki gruba ayrımıș olup163.1 mm ile 149.3 mm arasında değișim göstermiștir. En yüksek toprak nemi 60 cm sırt genișliği uygulamalarında
Çizelge 6. Sırt genișliğine göre 2015 yılı toprak nemi grupları

Table 6. Groups of soil moisture fort he year 2015 according to ridge width

\begin{tabular}{cc}
\hline Sırt Genișliği & $\begin{array}{c}\text { Ortalama Toprak Nemi } \\
\text { (0-90 cm) }(\mathrm{mm})\end{array}$ \\
\hline $30 \mathrm{~cm}$ & $149.3 \mathrm{~b}$ \\
$45 \mathrm{~cm}$ & $154.3 \mathrm{~b}$ \\
$60 \mathrm{~cm}$ & $163.1 \mathrm{a}$
\end{tabular}

(a) olup 45 ve $30 \mathrm{~cm}$ sırt genișliklerinin etkisi aynı (b) bulunmuștur. Her iki yılda ekim ve hasat arasında düșen yağıș miktarındaki farklılık sırt genișlikleri açısından farklı sonuçlar doğurmuștur. Gelișme döneminde 2014 yılında düșük yağıșlar nedeniyle sırt genișliklerinin toprak nemini artırması bakımından önemli bir artıșa yol açmadığı tespit edilmiștir.

Aylık toplam yağıș verilerinin istatistiksel değerlendirmesine göre uzun yıllar, 2014 ve 2015 yılları yağıș miktarları arasındaki fark önemsiz bulunmuștur (p>0.05). Ancak bitki yetișme döneminde özellikle bitkinin suya intiyaç duyduğu çiçeklenme gibi kritik dönemlerindeki yağıș uzun yıllara ait bu aylardaki yağıșlardan daha düșük olmuștur. Örneğin uzun yıllar ortalamasına göre mayıs, haziran ve temmuz aylarında sırasıyla $\% 10.2, \% 10.4$ ve \%2.5 yağıș alırken 2014 yılında sırasıyla \%6.3, \%9 ve \%0 ve 2015 yılında sırasıyla \%15.3, \%25.4 ve \%0 yağıș almıștır (C̣izelge 7). Bu, özellikle kurak alanlarda, yağıșın miktarı yanında yağdığı dönemin de verim üzerinde son derece etkili olduğunu göstermektedir.

Yıllar arasındaki yağıș miktarları arasındaki fark istatistiksel olarak önemsiz bulunmasına rağmen, yukarıda bahsedildiği gibi, bitki yetișme dönemi boyunca düșen yağıș miktarı 2014 yılında daha az olduğu için (Çizelge 7) tüm konularda toprak nem değerleri 2015 yılından daha düșük çıkmıștır. Denemenin yürütüldüğü aylar (mayıs, haziran, temmuz, ağustos) içinde en fazla yağıș 46.6 mm ile 2015 yılı haziran ayında gerçekleșmiștir. Haziran ayındaki bu yağıș miktarı toprakta depolanan nem üzerinde oldukça etkili olmuș ve tüm deneme boyunca en fazla toprak nemi 30.06.2015 tarihinde yapılan ölçüm sonucu elde edilmiștir ( $\mathrm{Pg}_{3}$ ortalama nem=294.6 mm). Yağıșlar sonucunda biriken toprak nemleri $(0-90 \mathrm{~cm})$ grafiksel olarak Șekil 3 ve Șekil 4'te gösterilmiștir. Bütün malç uygulamalarında sırt genișliğinin artmasıyla toprak nem içeriği artmıștır. Elde edilen 
Çizelge 7. Uzun yıllar, 2014 ve 2015 yılları aylık yağıșlarının değerlendirmesi

Table 7. Evaluation of long-term, 2014 and 2015 monthly precipitation

\begin{tabular}{lcccccc}
\hline & Uzun Ylllar Ort. & \multicolumn{2}{c}{2014} & \multicolumn{2}{c}{2015} \\
\hline Aylar & $\mathrm{mm}$ & $\%$ & $\mathrm{~mm}$ & $\%$ & $\mathrm{~mm}$ & $\%$ \\
\hline Ocak & 24.6 & 10.8 & 40.4 & 13.9 & 13.2 & 7.2 \\
Șubat & 22.7 & 9.9 & 18.4 & 6.3 & 24.9 & 13.6 \\
Mart & 18.8 & 8.2 & 47.2 & 16.3 & 42.6 & 23.2 \\
Nisan & 25.3 & 11.1 & 3.2 & 1.1 & 16.2 & 8.8 \\
Mayıs & 23.2 & 10.2 & 18.4 & 6.3 & 28.0 & 15.3 \\
Haziran & 23.7 & 10.4 & 26.0 & 9.0 & 46.6 & 25.4 \\
Temmuz & 5.8 & 2.5 & 0.0 & 0.0 & 0.0 & 0.0 \\
Ağustos & 2.6 & 1.1 & 9.8 & 3.4 & 5.2 & 2.8 \\
Eylül & 10.3 & 4.5 & 17.2 & 5.9 & 0.8 & 0.4 \\
Ekim & 17.4 & 7.6 & 48.2 & 16.6 & 3.6 & 2.0 \\
Kasım & 21.0 & 9.2 & 31.8 & 11.0 & 1.6 & 0.9 \\
Aralık & 32.8 & 14.4 & 29.8 & 10.3 & 0.6 & 0.3 \\
Toplam & 228.2 & 100.0 & 290.4 & 100.0 & 183.3 & 100.0 \\
\hline Std. Sapma & 8.7 & & 16.0 & & 16.7 & \\
Ortalama & 19.0 & & 24.2 & & 15.3 & \\
Minimum & 2.6 & & 0.0 & & 0.0 & \\
Maksimum & 32.8 & & 48.2 & & 46.6 & \\
\hline
\end{tabular}

bulgular Feng vd. (2012) bulgularıyla benzerdir. Sırt genișliği en fazla olan $(60 \mathrm{~cm})$ konularda toprak nemi en fazla olmuș, bunu sırasıyla $45 \mathrm{~cm}$ ve 30 $\mathrm{cm}$ sırt konuları takip etmiștir. Feng vd. (2012), $30 \mathrm{~cm}$ karık genișliği için plastik malç uygulanan $30 \mathrm{~cm}$ ve $60 \mathrm{~cm}$ sırt genișliklerini denemiș, her iki uygulamada da düz arazi üzerine kurulan kontrol konusundan daha fazla toprak nemi ölçmüș ve en fazla toprak nemi $60 \mathrm{~cm}$ sırt genișliği olan konuda olmuștur. Plastik malçlı sırtlarda buharlașma

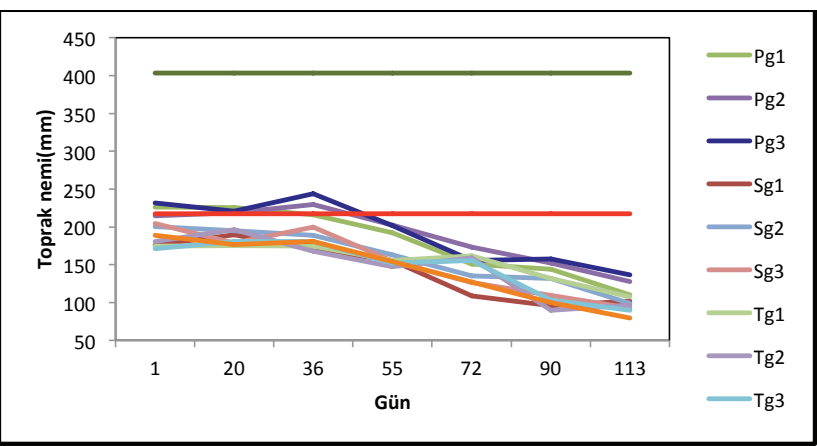

Șekil 3. 2014 yılı konulara göre toprak nem değerlerinin (mm) zamansal değișimi

Figure 3. Temporal variation of soil moisture values $(\mathrm{mm})$ by subjects in 2014 kayıplarının en az olması depolanan toprak nemi miktarında oldukça etkilidir. Plastik malçlı sırtlar önemli bir hasat etkinliğine sahiptir (Wang vd, 2008). Li vd. (2001)'in sıkıștırılmıș toprak sırt ve plastik malçlı sırtlarla yaptığı çalıșmanın sonuçlarına benzer șekilde her iki yılda da kontrol parseliyle karșılaștırıldığında toplam toprak nemi değerlerinde, en fazla nem plastik malçlı sırt konusunda belirlenmiștir.

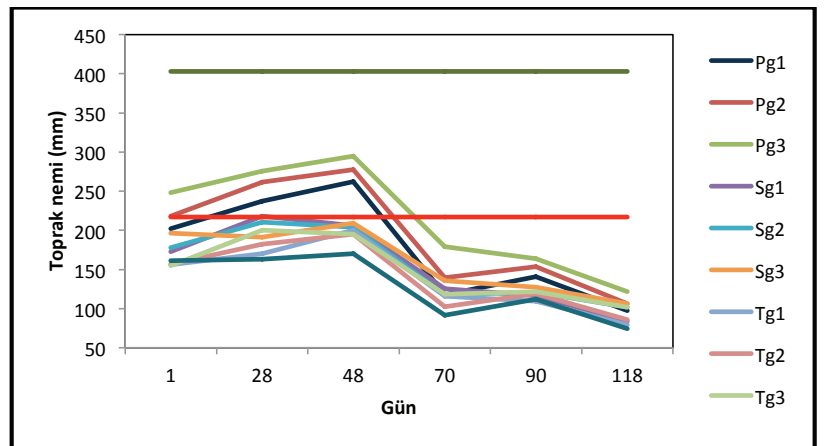

Șekil 4. 2015 yılı konulara göre toprak nem değerlerinin (mm) zamansal değișimi

Figure 4. Temporal variation of soil moisture values $(\mathrm{mm})$ by subjects in 2015 
Saman kaplı sırtlar sıkıștırılmıș toprak sırtlardan daha fazla nem artıșı sağlamıștır. Saman ve toprak sırtlarda buharlașma kayıplarının plastik sırtlara göre daha fazla olması, hem daha yoğun yağıșlarda ancak yüzey akıș vermeleri hem de sırtlar üzerinde yetișen yabancı otlar nedeniyle depolanan toprak nem miktarının plastik malçlı sırtlara göre daha az çıkmasına neden olmuștur. Ancak bu konulardaki toprak nemi hiçbir uygulama yapılmayan kontrol konusuna göre daha fazla bulunmuștur. Kontrol konusu geleneksel yöntemlerle düz arazi üzerine sırtsız ve karıksız olarak kurulduğu için bir yandan yüzey akıș, konsantre edilemediğinden toprakta sığ bir tabakada depolanmıș ve diğer yandan buharlașma kayıpları nedeniyle kaybedilmiștir. Yapılan araștırmalarda kavun için bitki su tüketimi Ankara koșullarında ortalama 565 mm (Yıldırım vd., 2009), Kayseri koșullarında ortalama 635 mm (Keskin, 2016) olarak belirlenmiștir. Karapınar koșullarında kavunun bitki su tüketimi $617,5 \mathrm{~mm}$ (Anonim, 2016b) olup tüm deneme süresince bütün konularda söz konusu neme ulașılamamıș hatta çoğu zaman solma noktası değerinin altında kalmıș dolayısıyla bitkisel üretimde ekonomik verim alınamamıștır. Bu nedenle verim bakımından istatistiksel değerlendirme yapılamamıștır. Diğer uygulamalarda her parselde meyve verimi alınamazken plastik örtülü sırt konularında sınırlı sayıda ve ekonomik değeri olmayan meyve elde edilmiș ve bitki bașına meyve sayısı bakımından $\mathrm{Pg}_{1}, \mathrm{Pg}_{2}$ ve $\mathrm{Pg}_{3}$ konularında 2014 yılında sırasıyla 0.47 adet, 0.42 adet ve 0.53 adet, 2015 yllında sırasıyla 0.59 adet, 0.67 adet ve 0.84 adet meyve elde edilmiștir.

\section{SONUC}

Bu çalıșma, kurak-yarı kurak alanlarda bitkisel üretimde verim artıșına yönelik toprak nemini artırma ve toprak yüzeyinden buharlașma miktarını azaltmak için yağıș sularından optimum fayda sağlamak amacıyla yürütülmüștür.

Yapılan çalıșmada elde edilen sonuçlara göre yağmur suyu hasadı için kullanılan sırt: karık mikro havza su hasadı sistemleri, kontrol konusuna göre toprak nemini artırmıștır. Toprak neminin bu artıșında sırtlardan hasat edilen suyun karıklarda konsantre edilerek toprakta daha derinlere sızarak depolanması ve buharlașma yüzeyinin azaltılması etkili olmuștur.

Plastik örtülü sırtlar, sap-saman örtülü sırtlar ve sıkıștırımıș toprak sırtlar ile karıklardan olușan mikro havza su hasadı sistemleri içerisinde toprak nemini en çok plastik örtülü sırtlar artırmıștır. Uygulanan plastik örtülü sırt konuları düșen yağıșları karıklara ve bitki kök bölgesine yönlendirmiș ancak diğer uygulamalar plastik malçlı sırt konuları kadar bașarıı olamamıștır. Su hasadının yapıldığı sırtların genișliğinin artmasına paralel șekilde toprak nemi de artmıștır. Saman kaplı sırtlarda sıkıștııımıs toprak sırtlardan daha fazla toprak nemi artıșı sağlanmıștır.

Etkili yağıș miktarının tamamı karıklara yönlendirilmesi nedeniyle en fazla hasat etkinliği plastik malçlı sırtlarda olmuș; sırasıyla $30 \mathrm{~cm}, 45$ $\mathrm{cm}$ ve $60 \mathrm{~cm}$ genișlik için $0.6,0.9$ ve 1.2 kat daha fazla yağıș hasat edilmiștir. Buna göre kontrol konusuyla karșılaștıııldığında plastik malç ile kaplı 60 cm genișliğindeki sırtlardan 2014 yılında $36.7 \mathrm{~mm}$ ve 2015 yılında $52.8 \mathrm{~mm}$ daha fazla yağıș hasat edilmiștir. Bu değerler $45 \mathrm{~cm}$ sırt genișliği için sırasıyla $27.5 \mathrm{~mm}$ ve $39.6 \mathrm{~mm}$ iken $30 \mathrm{~cm}$ genișliğindeki sırtlar için $18.4 \mathrm{~mm}$ ve 26.4 mm olmuștur. Görüldüğü gibi sırt genișliğinin artmasıyla birim alandan hasat edilen yağıș miktarı dolayısıyla toprakta depolanan nem miktarı artıș göstermiștir. Plastik malçlı sırt konularında hasat edilen yağıșın daha fazla olmasına rağmen düșen yağıșlar çok yetersiz kalmıș ve bitkisel üretimde ekonomik verim alınamamıștır. Böyle marjinal alanlarda daha büyük sırt genișliği olușturularak erozyonu önlemenin yanında tamamlayıcı sulama ile ekonomik verim alınması mümkün gözükmektedir.

\section{KAYNAKLAR}

Anonim a. (2016). http://wmw.karapinar.gov.tr. TC Karapınar Kaymakamlığı resmi internet sitesi.

Anonim b. (2016). Türkiye'de Sulanan Bitkilerin Bitki Su Tüketimi Rehberi. TAGEM-DSi. Ankara

Boers T.M, Ben-Asher J (1982). A Review of Rainwater Harvesting. Agricultural Water Management, 5: 145-158

Boers T.M, Zondervan K, Ben-Asher J (1986). MicroCatchment Water Harvesting for Arid Zone Development. Agricultural Water Management, 12: 21-39

Critchley W. Siegert K. (1991). Water Harvesting: a Manual for the Design and Construction of Water harvesting Schemes for Plant Production. FAO, Rome.

Fabeiro, C., de santa Olalla, M., de juan, J.A., 2001 . Yield and Size of Deficit Irrigated Potatoes. Agri. Water Manag. 18, 255-266.

Feng H, Kun W, Lin L-X, Xia L-G (2012). Effects of Ridge and Furrow Rainfall Harvesting System on Elymus Sibiricus Yield in Bashang Agro-pastoral Zone of China. African journal of Biotechnology Vol. 11 (38), p $9175-9181$ 
Keskin, G. (2016). Kısıtlı Sulama Koșullarında Kavunda Anaç Kullanımının Bitkisel Gelișime ve Verime Etkisi. Erciyes Üniversitesi Fen Bilimleri Enstitüsü Biyosistem Mühendisliği Anabilim Dalı (Yüksek Lisans Tezi).

Li X-Y, Gong J-D, Wei X-H (2000). In-Situ Rainwater Harvesting and Gravel Mulch Combination for Corn Production in the Dry Semi-arid Region of China. Journal of Arid Environment, 46:371-382

Li X-Y, Gong J-D, Gao O-Z, Li, F-R (2001). Incorporation of Ridge and Furrow Method of Rainfall Harvesting With Mulching For Crop Production Under Semi-Arid Conditions. Agricultural Water Management, 50: 173-183

Li X., Su D. and Yuan O. (2007). Ridge-Furrow Planting of Alfalfa (Medicago sativa L.) for Improved Rainwater Harvest in Rainfed Semiarid Areas in Northwest China. Soil \& Tillage Research 93: 117-125

MGM, (2016). Meteoroloji Genel Müdürlüğü Verileri
Oweis T, Hachum A (2000). Water Harvesting And Supplemental Irrigation for Improved Water Use Efficiency. Advanced Short Course on Water Saving in Irrigated Agriculture. Cairo.

Pamuk Mengü G, Akkuzu E (2008). Küresel Su Krizi ve Su Hasadı Teknikleri. ADÜ Ziraat Fakültesi Dergisi, 5: 75-85

Tian Y, Su D, Li F, li X (2003). Effect of Rainwater Harvesting with Ridge and Furrow on Yield of Potato in Semiarid Areas Field Crops Research 84: 385-391

Wang O, Zhang E, Li F, Li F (2008). Runoff Efficiency and the Tecnique of Micro-water Harvesting with Ridges and Furrows, for Potato Production in Semi-arid Areas. Water Resor Manage, 22: 1431-1443.

Yıldırım, O., Halloran N., Çavușoğlu, Ș., Șengül, N. (2009). Effects of Different Irrigation Programs on the Growth, Yield and Fruit Quality of Drip-irrigated Melon. Turkish Journal of Agriculture and Forestry, 33: 243-255. 